\title{
Experimental generation of STKN540B steel circular tube manufacture with press bending and auto-welding correction
}

\author{
Dongkyu Lee ${ }^{*}$, Sungmin $\mathrm{Joo}^{2}$, Ji Zhang ${ }^{3}$ \\ ${ }^{1}$ Department of Architectural Engineering, Sejong University, Seoul, Republic of Korea \\ ${ }^{2}$ School of Civil Engineering and Mechanics, Huazhong University of Science and Technology, China \\ ${ }^{3}$ Department of Welding and Joining Science Engineering, Chosun University, Gwangju, Republic of Korea \\ *Corresponding author. E-mail: dongkyulee@ sejong.aac.kr
}

\begin{abstract}
The purpose of this study is to propose a consecutive manufacturing process system to secure the productivity of excellent STKN540B steel tube in the respect of economy and safety as the supporting material for mega structures such as building, bridge and ship. The components of consecutive manufacturing are press-bending, orbital auto welding and steel tube correction. By using STKN540B a high-strength steel material with low yield point that requires a special manufacturing process unlike other steel materials, an actual tube manufacturing is carried out at each stage in this experimental study. With this, the quality of steel tube and the efficiency of the manufacturing process are analyzed to draw out some points to improve in the future.
\end{abstract}

Keywords: Press Bending; Orbital Auto Welding; Steel-tube Correction; STKN540B; Highstrength Steel Tube; Manufacturing Process

\section{Introduction}


Cylindrical steel tubes are classified into cold-formed ones (Yu, 1999; Hancook, 2003; Im et al., 2004) and hot-formed ones (Yanagimoto et al., 1998; Gueler, 2013). To secure the safety for mega structures, high-strength tubes are used. The cylindrical tubes of CFT structure for girder (Lopes et al., 2015, Morino et al., 2001; Park and Lee, 2013; Xu et al., 2017; Wang et al. 2019) include the electric resistance welded tube, arc welded tube and centrifugal cast tube. As shown in Table 1, the outer diameter and plate thickness of producible steel tube are determined by the manufacturing method. The electric resistance welded tubes and the arc welded tubes are cold-formed, and the centrifugal cast tubes are hot-formed. The manufacturing method of steel tube mainly depends on the type of steel. According to the thickness and diameter of steel material, the mechanical natures of tube such as tensile strength, yield point, elongation and Charpy Absorption Energy in Table 2 and 3 are determined (Kim et al., 2008; Luecke et al., 2005). Especially in case of building structure tubes that are usually used for mega structures such as ship, building and bridge, Charpy Absorption Energy is generally considered to secure the safety.

Table 1. Manufacturing Methods of Steel Tube and their Characteristics

\begin{tabular}{|c|c|c|c|c|}
\hline Tube Type & $\begin{array}{c}\text { Manufacturing } \\
\text { Method }\end{array}$ & Steel Type & Outer Diameter ${ }^{* 1}$ & Plate Thickness ${ }^{* 2}$ \\
\hline $\begin{array}{c}\text { Arc Welding } \\
\text { Steel Tube }\end{array}$ & $\begin{array}{c}\text { - UO Presser } \\
\text { - Press Bend }\end{array}$ & $\begin{array}{c}\text { Carbon Steel and } \\
\text { Stainless Steel }\end{array}$ & $\begin{array}{c}\text { Large } \sim \text { Middle } \\
\text { Ultra Large } \sim \\
\text { Large }\end{array}$ & $\begin{array}{c}\text { Thick } \sim \text { Middle } \\
\text { Ultra Thick } ~ \\
\text { Middle }\end{array}$ \\
\hline $\begin{array}{c}\text { Electric } \\
\text { Resistance } \\
\text { Welded Tube }\end{array}$ & $\begin{array}{c}\text { Electric } \\
\text { Resistance } \\
\text { Welding }\end{array}$ & Carbon Steel & Middle $\sim$ Small & Middle $\sim$ Thin \\
\hline
\end{tabular}




\begin{tabular}{|l|c|c|l|c|}
\hline Cast Steel Tube & $\begin{array}{c}\text { Centrifugal } \\
\text { Casting }\end{array}$ & Carbon Steel & Large $\sim$ Middle & $\begin{array}{c}\text { Ultra Thick } ~ \\
\text { Middle }\end{array}$ \\
\hline
\end{tabular}

Outer Diameter ${ }^{*}$

\begin{tabular}{|c|c|c|c|}
\hline Ultra Large & Large & Middle & Small \\
\hline$>2,500 \mathrm{~mm}$ & $>700 \mathrm{~mm}$ & $>100 \mathrm{~mm}$ & $<100 \mathrm{~mm}$ \\
\hline
\end{tabular}

Plate Thickness ${ }^{* 2}$

\begin{tabular}{|c|c|c|c|}
\hline Ultra Thick & Thick & Middle & Thin \\
\hline$>40 \mathrm{~mm}$ & $>25 \mathrm{~mm}$ & $>6 \mathrm{~mm}$ & $<6 \mathrm{~mm}$ \\
\hline
\end{tabular}

Table 2. Mechanical Nature of Steel Tube - KS D 3566(General Structure Carbon Steel

Tube)-1

\begin{tabular}{|c|c|c|c|c|c|}
\hline \multirow{3}{*}{ Classification } & \multirow{3}{*}{$\begin{array}{c}\text { Tensile } \\
\text { strength } \\
\mathrm{N} / \mathrm{mm}^{2}\end{array}$} & \multirow{3}{*}{$\begin{array}{l}\text { Yield Point } \\
\qquad \mathrm{N} / \mathrm{mm}^{2}\end{array}$} & \multicolumn{2}{|c|}{ Elongation (\%) } & \multirow{3}{*}{$\begin{array}{c}\text { Tensile strength of } \\
\text { welded part } \\
\mathrm{N} / \mathrm{mm}^{2}\end{array}$} \\
\hline & & & $\begin{array}{l}\text { No.11 Specimen } \\
\text { No.12 Specimen }\end{array}$ & No.5 Specimen & \\
\hline & & & vertical & horizontal & \\
\hline $\begin{array}{l}\text { Outer } \\
\text { Diameter } \\
\text { type }\end{array}$ & $\begin{array}{c}\text { Total outer } \\
\text { diameter }\end{array}$ & $\begin{array}{c}\text { Total outer } \\
\text { diameter }\end{array}$ & \multicolumn{2}{|c|}{ Over $400 \mathrm{~mm}$} & Over $350 \mathrm{~mm}$ \\
\hline STK 290 & 290 or up & - & 30 or up & 25 or up & 290 or up \\
\hline STK 400 & 400 or up & 235 or up & 23 or up & 18 or up & 400 or up \\
\hline STK 490 & 490 or up & 315 or up & 23 or up & 18 or up & 490 or up \\
\hline STK 500 & 500 or up & 355 or up & 15 or up & 10 or up & 500 or up \\
\hline STK 540 & 540 or up & 390 or up & 20 or up & 16 or up & 540 or up \\
\hline
\end{tabular}

Table 3. Mechanical Nature of Steel Tube - KS D 3632(Building Structure Carbon Steel

Tube)-2 


\begin{tabular}{|c|c|c|c|c|c|c|c|c|}
\hline \multirow{2}{*}{ Symbol } & \multirow{2}{*}{$\begin{array}{c}\text { Tensile } \\
\text { strength } \\
\mathrm{N} / \mathrm{mm}^{2}\end{array}$} & \multicolumn{2}{|c|}{$\begin{array}{l}\text { Yield point } \\
\qquad \mathrm{N} / \mathrm{mm}^{2}\end{array}$} & \multicolumn{2}{|c|}{$\begin{array}{c}\text { Yield Ratio } \\
\mathrm{N} / \mathrm{mm}^{2}\end{array}$} & \multirow{2}{*}{$\begin{array}{c}\text { Elongation } \\
\%\end{array}$} & \multirow{2}{*}{$\begin{array}{c}\text { Charpy } \\
\text { Absorption } \\
\text { Energy }\end{array}$} & $\begin{array}{c}\text { Tensile } \\
\text { strength of } \\
\text { welded part }\end{array}$ \\
\hline & & $\begin{array}{c}\text { Thick } \\
\text { mm }\end{array}$ & & $\begin{array}{c}\text { Thick } \\
\text { mm }\end{array}$ & & & & Arc Weld \\
\hline $\begin{array}{l}\text { STKN } \\
400 W\end{array}$ & $\begin{array}{c}400 \text { or up } \\
540 \text { or } \\
\text { down }\end{array}$ & $\begin{array}{l}100 \text { or } \\
\text { down }\end{array}$ & 235 or up & $\begin{array}{l}100 \text { or } \\
\text { down }\end{array}$ & - & 23 or up & - & 400 or up \\
\hline \multirow{3}{*}{$\begin{array}{l}\text { STKN } \\
400 B\end{array}$} & \multirow{3}{*}{$\begin{array}{c}400 \text { or up } \\
540 \text { or } \\
\text { down }\end{array}$} & $\begin{array}{c}\text { Lower than } \\
12\end{array}$ & 235 or up & $\begin{array}{c}\text { Lower than } \\
12\end{array}$ & - & \multirow{3}{*}{23 or up } & \multirow{3}{*}{27 or up } & \multirow{3}{*}{400 or up } \\
\hline & & $\begin{array}{c}12 \text { or up } \\
40 \text { or } \\
\text { down }\end{array}$ & $\begin{array}{l}235 \text { or up } \\
385 \text { or up }\end{array}$ & $\begin{array}{c}12 \text { or up } \\
40 \text { or } \\
\text { down }\end{array}$ & $\begin{array}{c}80 \text { or } \\
\text { down } \\
(1)\end{array}$ & & & \\
\hline & & $\begin{array}{c}\text { Higher than } \\
40 \\
100 \text { or } \\
\text { down }\end{array}$ & $\begin{array}{c}215 \text { or up } \\
365 \text { or } \\
\text { down }\end{array}$ & $\begin{array}{c}\text { Higher than } \\
40 \\
100 \text { or } \\
\text { down }\end{array}$ & $\begin{array}{c}80 \text { or } \\
\text { down } \\
(1)\end{array}$ & & & \\
\hline \multirow{3}{*}{$\begin{array}{l}\text { STKN } \\
490 B\end{array}$} & \multirow{3}{*}{$\begin{array}{c}490 \text { or up } \\
640 \text { or } \\
\text { down }\end{array}$} & $\begin{array}{c}\text { Lower than } \\
12\end{array}$ & 325 or up & $\begin{array}{c}\text { Lower than } \\
12\end{array}$ & - & \multirow{3}{*}{23 or up } & \multirow{3}{*}{27 or up } & \multirow{3}{*}{490 or up } \\
\hline & & $\begin{array}{c}12 \text { or up } \\
40 \text { or } \\
\text { down }\end{array}$ & $\begin{array}{c}325 \text { or up } \\
475 \text { or } \\
\text { down }\end{array}$ & $\begin{array}{c}12 \text { or up } \\
40 \text { or } \\
\text { down }\end{array}$ & $\begin{array}{c}80 \text { or } \\
\text { down } \\
(1)\end{array}$ & & & \\
\hline & & $\begin{array}{c}\text { Higher than } \\
40 \\
100 \text { or } \\
\text { down }\end{array}$ & $\begin{array}{l}295 \text { or up } \\
445 \text { or up }\end{array}$ & $\begin{array}{c}\text { Higher than } \\
40 \\
100 \text { or } \\
\text { down }\end{array}$ & $\begin{array}{c}80 \text { or } \\
\text { down } \\
(1)\end{array}$ & & & \\
\hline
\end{tabular}

$\left.{ }^{1}\right)$ In case of welded steel tube, the yield ratio is $85 \%$ or down.

Electric Resistance Welded Steel Tube is manufactured in the way that the hot-is coils are formed in cylinder consecutively by cold roll and then their joints are welded in the length by the high frequency electric resistance welding method. The manufacturing of large-diameter steel tube by arc welding includes the UO method and the press bending method. The UO steel tube is the one that the thick plate is formed by cold press. The outer diameter and thickness of steel tube are determined by the press capacity. After the thick plate is bent in $U$-shape by the $U$ press, it is formed into the tube by the $O$ press. 
The inner and outer sides of the steel tube are joined with the submerge arc welding. In the centrifugal casting method, the melted metal is poured into the rotating cast to from the tube by the centrifugal force.

Figure 1 is the general manufacturing view of steel tube (Lee and Shin, 2014, 2015). After manufacturing, a test is made to evaluate the productivity of the steel tube. In advance, it is necessary to decide the size of steel tube to produce and its test plan (Peng et al., 2012).
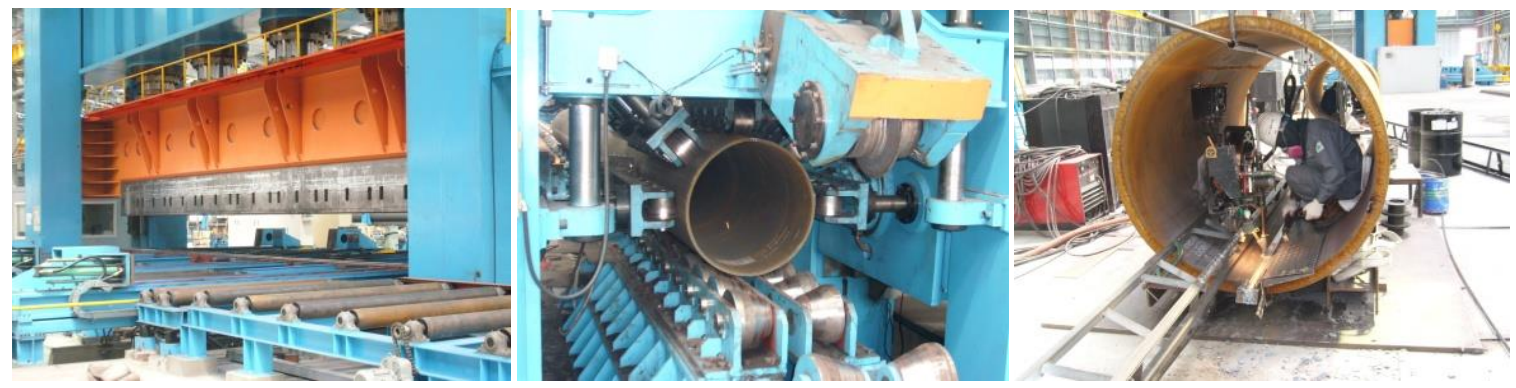

Figure 1. Field View of Steel Tube Manufacturing

In the manufacturing of CFT girder for mega structures, its main process is to cut the steel tubes and to join the cut tubes by welding. The greatest problem in the work is the difficulty of welding due to the roundness deviation, which causes the delay of construction period, quality degradation and economic losses (Watari and Ona, 2001; Moles and Ginzel, 2012; Cho et al., 2007).

The steel-tube manufacturing method dealt with in this study is the press-bend method for mega structures (lyengar, 1972; Ali and Moon, 2007), where the steel plate is rolled in a cylindrical form by the cold press and then joined by the submerge arc welding. The range for outer diameter and plate thickness of producible steel tube is fairly wide. To maximize the manufacturing efficiency in the field, the use of hot press bending (Okui et 
al., 2006; Ceclan et al., 2011; Gan and Kim, 2013) and tube expander (Zhu and Matsubara, 1996; Ahn et al., 2008, Song et al., 2009) is usually required. Especially when the steel tube is manufactured with the steel plate of $600 \mathrm{MPa}$ or higher tensile strength and of $80 \sim 100 \mathrm{~mm}$ ultra-thickness, it is critically necessary to secure the quality. But in the actual fields, the workers are depending on the conventional high frequency bending (Lee et al., 2011; Silva et al., 2012) or empirical way of trial and error so much that they can hardly realize the scientific manufacturing.

Therefore, it has become urgent to develop the portable roundness correction technology and welding device that can be applied to the manufacturing fields. This study proposes an improved method in respect of the device for more efficient manufacturing. In advance, as the design elements to realize the high-quality steel tube manufacturing method during the press bending, auto welding and expanding of high strength steel tubes such as SM490B of 600MPa tensile strength or STKN490B (Kim et al., 2008; Cha and Kim, 2013) on KS standard, it is necessary to secure the optimum welding condition for high strength steel tube through the welding groove design of its inner and outer sides and appropriate welding procedure (Kim et al., 2005; Kim et al., 2013). Furthermore, it is necessary to analyze the press schedule on the basis of work hardening degree, for the steel suffers the work hardening of about $6 \%$ (in case of $40 t \times 700 \Phi$ ) during the press forming (Gupta, 2002; Yang et al., 2012).

The contents of this study are as follows: Section 2 explains the specification of hot bender as well as the test plan and results; Section 3 deals with the specification of C-type jig, or the tube expander containing the outer-side correction device, analyzing its test 
plan and results; Section 4 explains the specification of Orbital auto welding along with the test plan and results; In Section 5, the conclusion of this study is described..

\section{Basic Test Plan for Hot Bender and Test Results}

\subsection{Basic Test Plan for Hot Bender}

To maximize the manufacturing efficiency of high-strength steel tube and to stabilize its quality, it is necessary to secure the manufacturing technology of cylindrical steel tube which is widely used in the bridge construction and the energy industries. This chapter deals with the problems in bending the steel plate to form a tube, for this study has the purpose to improve the demerits of conventional highfrequency bending and develop a new bend forming technology. To draw out the results appropriate for the circular treatment of cylindrical steel tube, it is very to manufacture the precise hot bending tester. But, because of the restrictions in the study, we set the detailed goal to draw out the appropriate value of curvature along with the factors that can make the maximum curvature due to the heat expansion of steel material, though the precision might get a little lower, and then manufactured the hot bending tester of specification shown in Table 4.

Table 4. Specification of Heat Bending Tester

\begin{tabular}{|c|c|}
\hline Division & Description \\
\hline $\begin{array}{c}\text { Basic } \\
\text { Specification }\end{array}$ & $\begin{array}{l}\text { Yield Strength of Steel Type: } 600 \mathrm{MPa} \text { (POSCO specimen of } 600 \mathrm{MPa} \text { tensile } \\
\text { strength) } \\
\text { Steel Tube : } \varnothing 1,200 \text { (outer diameter) } \\
\text { Curvature radius: R39 }\end{array}$ \\
\hline Feature & $\begin{array}{l}\text { As it is a mild forming with small curvature }(120 \mathrm{~mm} \text { for each length of } 6,000 \mathrm{~mm}) \text {, it } \\
\text { is necessary to draw out the natural curve through the difference of linear expansion } \\
\text { between heating and cooling at the temperature that may not cause the deformation } \\
\text { of material }\left(1,040^{\circ} \mathrm{C} \text { or lower). }\right.\end{array}$ \\
\hline
\end{tabular}




\begin{tabular}{|c|c|}
\hline $\begin{array}{c}\text { Curvature } \\
\text { Type }\end{array}$ & $\begin{array}{l}\text { 1st: The bending part is heated with gas torches (12ea), and then cooled with water } \\
\text { to secure the goaled curvature through the heat expansion and shrink of material. } \\
\text { 2nd: When the goaled curvature is not acquired in the } 1^{\text {st }} \text { bending, } R \text { Jig is installed in one } \\
\text { direction from the center of curved part and then the bending part is pressed with it until } \\
\text { the goaled curvature is achieved. }\end{array}$ \\
\hline Others & $\begin{array}{l}\text { When there is some size deformation in the outer diameter, it is necessary to } \\
\text { consider the Internal jig to secure the size. } \\
\text { The quality should be no lower than that of high-frequency bending. }\end{array}$ \\
\hline
\end{tabular}

\subsection{Test Method of Heat Bender}

The heat bending tester was manufactured as shown in Figure 2 and, before the test of $600 \mathrm{MPa}$ specimens in Tables 2 and 3, a simulation test was carried out for the specimen with lower tensile strength as shown in Table 5 to find out the appropriate temperature and time to generate the curve of steel plate due to the heating and cooling.

Table 5. Specification of Test Specimen

\begin{tabular}{|c|c|c|c|c|}
\hline Classification & Steel Type & Diameter $(\mathrm{mm})$ & Thickness $(\mathrm{mm})$ & Length $(\mathrm{mm})$ \\
\hline Case 1 & SM 490A & 1,200 & 20 & 3,000 \\
\hline Case 2 & STK 400A & 1,016 & 12 & 3,000 \\
\hline
\end{tabular}

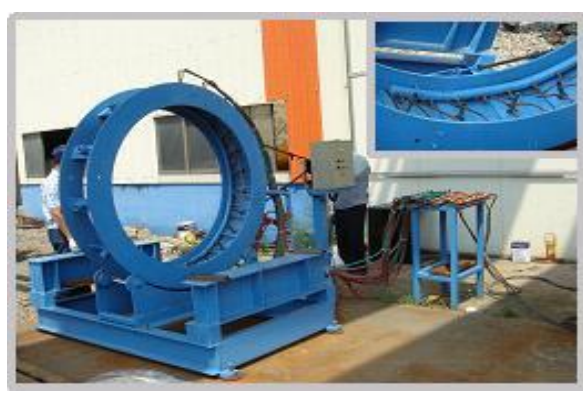

(a) Setting of Bender

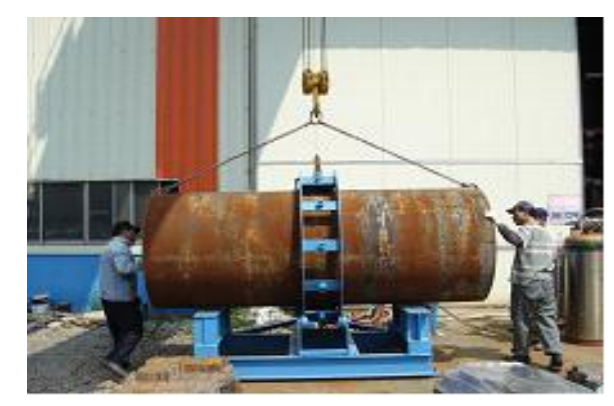

(b) Installation of Steel Tube (Specimen) 


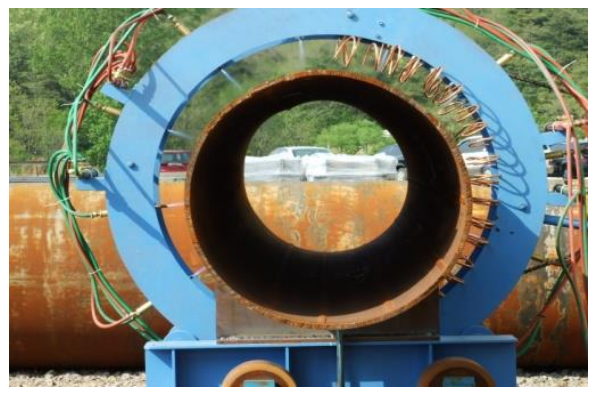

(c) Heating and Water Cooling of Tube

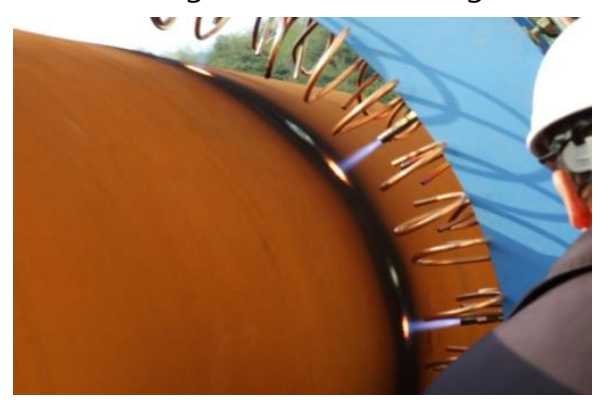

(e) Details in heating and water cooling of Tube

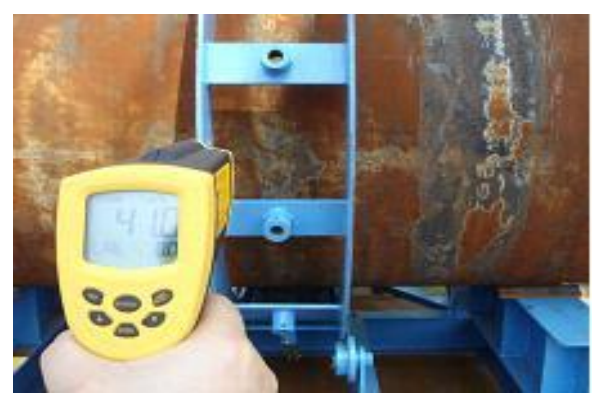

(d) Measurement of Steel Surface Temperature

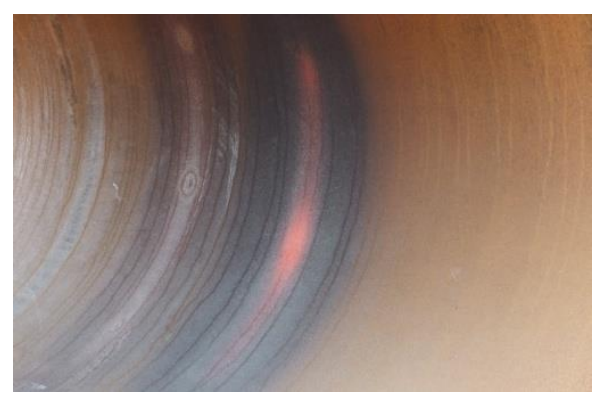

(f) Details in heated part of steel tube

Figure 2. Setting of Heat Bending Tester and Simulation Test

For the test, the specimen is set up while the center of the specimen comes to the center of tester. Then, only a half part of the tube specimen was heated and water cooled to make the deformation according to the surface temperature difference between heated and unheated parts. The surface temperature of specimen was measured before the test, 2 minutes after starting the test and every 6 minutes since then, while checking the deformation or so in the specimen. The result of the test is this: in the heating of the specimen with torches(12 ea) as shown in Table 3, the surface temperature of steel tube could be maintained up to $810^{\circ} \mathrm{C}$ but the test could not be carried out any longer because of the rupture on the temporary joint part of tube and the melting-down of torches in the tester.

\subsection{Test Result of Heat Bender and Discussion}

Table 6 and Figure 3 show the test result of heat bender, which can be summarized as follows:

(1) As a result of simulation test with heat bending tester, Case 1 had the rupture on the temporary joint 
part of specimen at about $500^{\circ} \mathrm{C}$ and it was impossible to check the possibility of curve forming for the specimen. The rupture of temporary joint part seemed to have been caused by the heat expansion of material. When the welding is incomplete, the welded part may be open during the work. So, special attention is required about it.

(2) In Case 2, the gas torches were melt down during the test and the heating was stopped. And the cooling start time was delayed, degrading the reliability of test results. The heating problem causing the melting-down of gas torches seems to be solved to some degree if the frame of torch part is changed into the open section that can be ventilated freely. In addition, it seems necessary to find out the ways to supply the cooling water into the heating part and to use the special material for torches.

Table 6. Test Result [Unit $\left.{ }^{\circ} \mathrm{C}\right]$

\begin{tabular}{|c|c|c|c|c|c|c|}
\hline \multirow{3}{*}{ Time } & \multicolumn{6}{|c|}{ Surface Temperature $\left({ }^{\circ} \mathrm{C}\right)$} \\
\hline & \multicolumn{3}{|c|}{ Case 1} & \multicolumn{3}{|c|}{ Case 2} \\
\hline & $\begin{array}{c}\text { Outside } \\
\text { Temperature }\end{array}$ & $\begin{array}{c}\text { Inside } \\
\text { Temperature }\end{array}$ & Remark & $\begin{array}{c}\text { Outside } \\
\text { Temperature }\end{array}$ & $\begin{array}{c}\text { Inside } \\
\text { Temperature }\end{array}$ & Remark \\
\hline Initial & 41 & - & - & 38 & - & - \\
\hline $2 \min$ & 375 & - & - & 400 & - & - \\
\hline $8 \min$ & 495 & - & $\begin{array}{c}\text { Rupture of } \\
\text { temporary } \\
\text { joint }\end{array}$ & 512 & - & - \\
\hline $14 \min$ & 706 & 776 & - & 778 & 801 & - \\
\hline $20 \min$ & 750 & 805 & No Curve & 810 & 866 & $\begin{array}{c}\text { Tordhes melt } \\
\text { down } \\
\text { (Curve: about } \\
\text { 1mm) }\end{array}$ \\
\hline
\end{tabular}




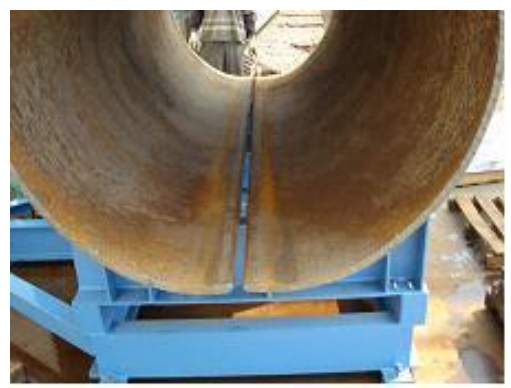

(a) Rupture of Temporary Joints(about $500^{\circ} \mathrm{C}$ )

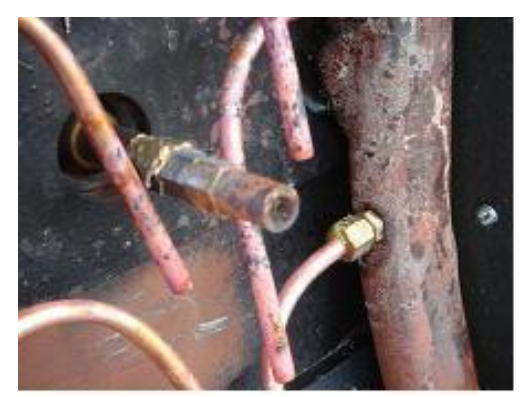

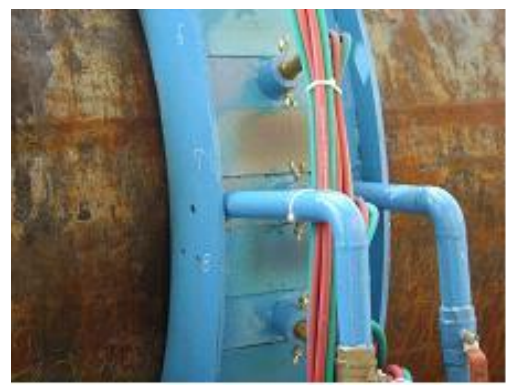

(b) Discoloration of Frame due to overheating

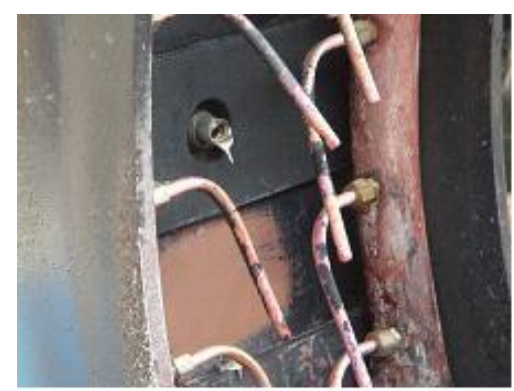

(c) Melting-down of Torches(2 ea) due to heat-blocking of frame

Figure 3. Test Results

In the result of this test, the items to complemented are as follows:

(1) In the simulation test, it seems hard to secure the goaled radius of steel tube just through the heat bending tester. To secure the goaled radius, it seems better to install the $\mathrm{R}$ Jig in one direction from the center of curved part along with this tester and press the bending part with the hydraulic cylinder until the curvature is achieved. But, the pressing of curved part with the hydraulic cylinder should be promoted only after finding out the measures to secure the roundness of curved part.

(2) Due to the restrictions such as fund and research period, this study suffered the problems in solving the problems during the test. The simulation hour was not sufficient. Furthermore, the control of tester and the data collection were made manually rather 
than automatically. Because of this poor environment, the reliability of the test result might be low. So, it is recommended to elevate the reliability of the test by introducing the automatic system and securing the sufficient research period in the future.

\section{Basic Test Plan for Tube Expander and Test Results}

\subsection{Basic Test Plan for Tube Expander}

The structures using the steel tubes are produced in the plants through Press Bending or Roll Bending and sent to the construction fields. During the transportation of steel tubes and the construction works, the partial deformation of tube frequently happens. So, it has been a great problem to secure the roundness of tubes. When the partial deformation of a steel tube happens in the field, the tube has to be sent back to the plant for the correction because the conventional corrector lacks the mobility. It inevitably delays the construction period and causes the additional cost. To solve this problem, a portable tube correction system was invented that can correct the partial deformation of tube in the field. The correction system comprises the tube expander in Figure 4 and Table 7 and the outer-side correction device or CTYPE JIG in Figure 5 and Table 8. The specification of specimen is presented in Table 9.
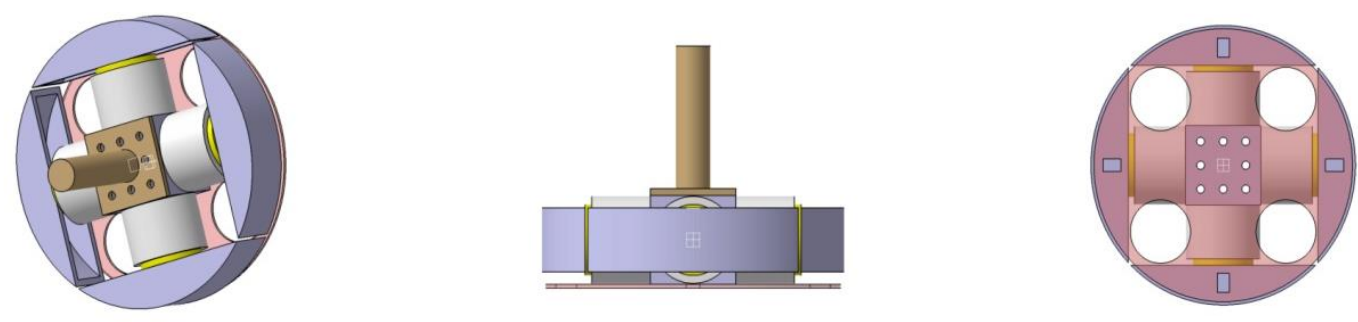

Figure 4. Tube Expander 

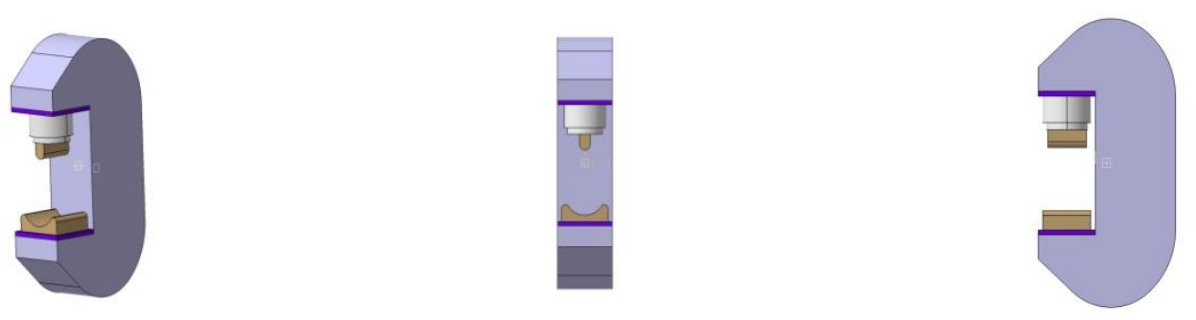

Figure 5. C-type Jig

Table 7. Specification of Tube Expander

\begin{tabular}{|c|l|}
\hline Division & \multicolumn{1}{c|}{ Description } \\
\hline $\begin{array}{c}\text { Basic } \\
\text { Specification }\end{array}$ & $\begin{array}{l}\text { Dimension of main body: } 1050 \times 240 \times 150 \mathrm{~mm} \\
\text { Pressure to use: } 600 \mathrm{MPa} \\
\text { Expansion Range: } 800 ~ 1500 \mathrm{~mm}\end{array}$ \\
\hline Features & $\begin{array}{l}\text { Easy to move and re-install. } \\
\text { Little restriction according to field conditions. } \\
\text { Can correct the steel tube of diverse size by changing the jig types. }\end{array}$ \\
\hline $\begin{array}{c}\text { Curving } \\
\text { Method }\end{array}$ & $\begin{array}{l}\text { After installing the expansion jig inside the deformed steel tube, give } \\
\text { pressure to each direction to correct it. }\end{array}$ \\
\hline
\end{tabular}

Table 8. Specification of C-TYPE JIG (Outer-side Correction Device)

\begin{tabular}{|c|l|}
\hline Division & \multicolumn{1}{c|}{ Description } \\
\hline $\begin{array}{c}\text { Basic } \\
\text { Specification }\end{array}$ & $\begin{array}{l}\text { Dimension of main body: } 600 \times 1050 \times 802 \mathrm{~mm} \\
\text { Pressure to use: } 600 \mathrm{MPa} \\
\text { Expansion Range: Regardless of diameter. Max. thickness - 30mm. }\end{array}$ \\
\hline Features & $\begin{array}{l}\text { Easy to move and re-install, little restriction in location, and easy to correct } \\
\text { the partial deformation. } \\
\text { For the partial deformation that cannot be corrected by tube expander or } \\
\text { for the minute deformation, it can make effective correction. }\end{array}$ \\
\hline $\begin{array}{c}\text { Curving } \\
\text { Method }\end{array}$ & $\begin{array}{l}\text { After positioning the deformed part inside the jig, apply the pressure in the } \\
\text { both directions to correct the partial deformation. }\end{array}$
\end{tabular}


Table 9. Specification of Specimen (for Actual Test)

\begin{tabular}{|c|c|c|}
\hline Steel Type & Diameter $(\mathrm{mm})$ & Thickness $(\mathrm{mm})$ \\
\hline SM490B & 1,100 & 14 \\
\hline
\end{tabular}

\subsection{Test Method of Tube Expander}

The test orders of tube expander and C-TYPE JIG are shown in Figure 6 and Figure 7 respectively or as follows:

(1) Apply the external force to a pre-manufactured steel tube to make a partial deformation.

(2) Set the tube expanding jig inside the partially deformed specimen for the test. And, for the C-TYPE JIG test, locate the partially deformed section between the jig teeth.

(3) Measure the size of deformed part with a measuring device (Vernier Calipers).

(4) Operate the tube expander / C-TYPE JIG to secure the roundness.

(5) After test, check the size of deformed part.

(6) Compare the sizes of deformed part before and after the test.
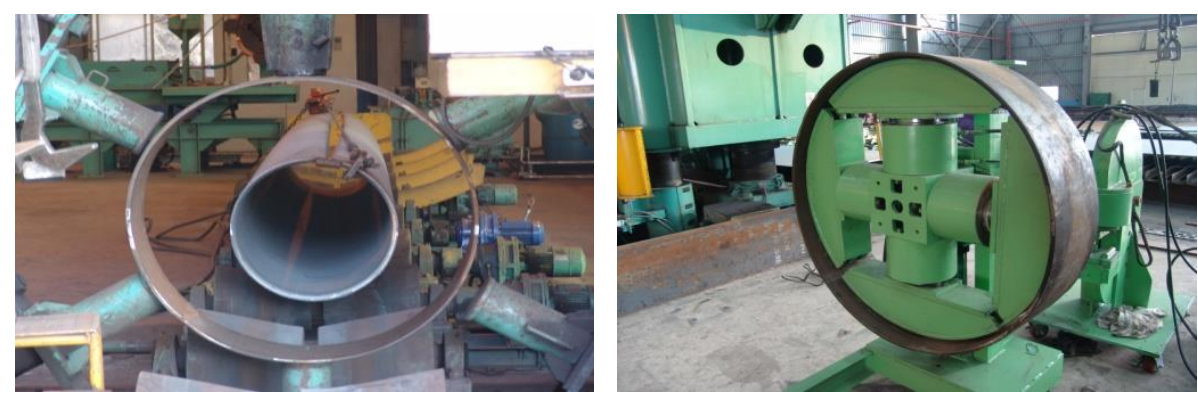

(a) Partial deforming of steel tube (b) Installation of tube expander 


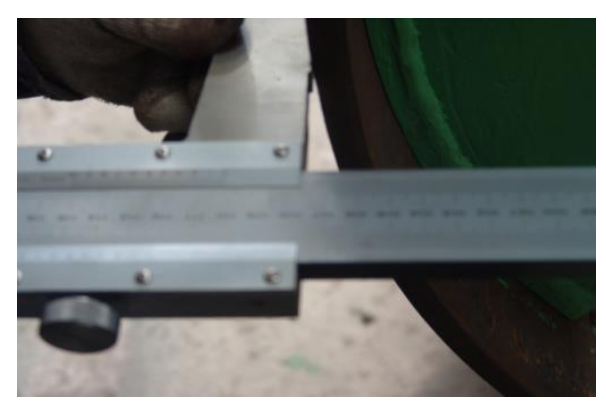

(c) Measuring of partial deformation

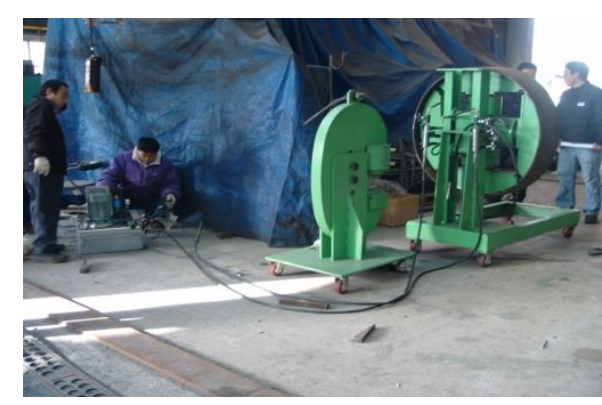

(d) Operation of C-type Jig

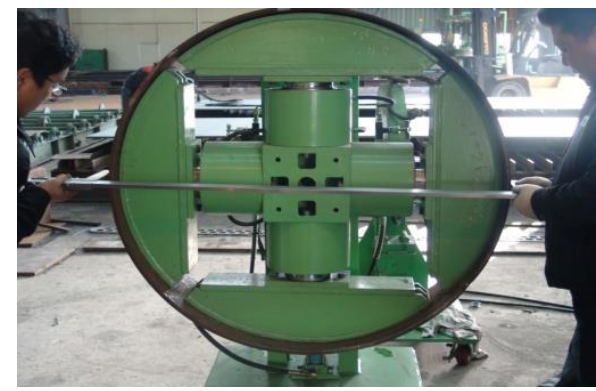

(e) Measuring of deformation after test

Figure 6. Tube Expander Tes
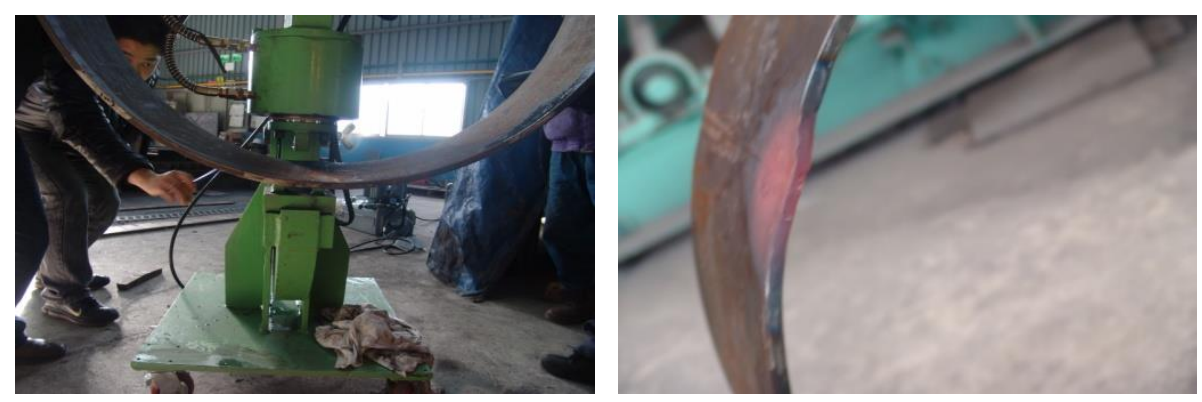

(a) Installation of C-TYPE JIG

(b) Steel tube after correction of outside surface

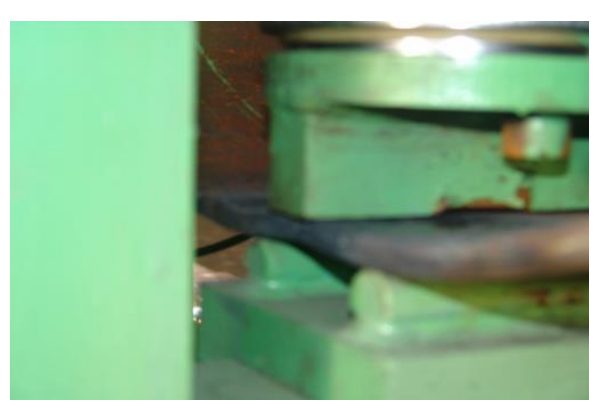

(c) Early stage of outside correction

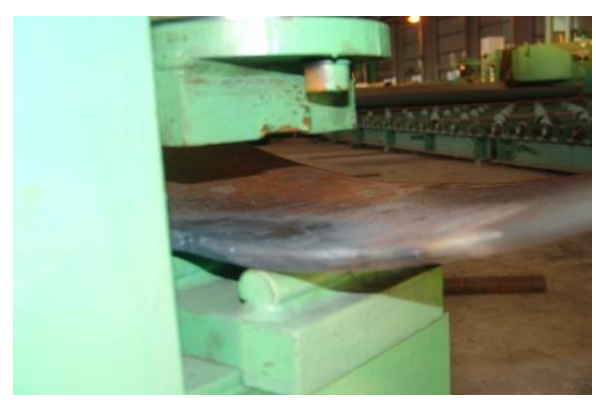

(d) Moving stage of outside correction

Figure 7. C-TYPE JIG Test

\subsection{Test Result of Tube Expander and Discussion}


As can be seen in Table 10 and 11, diameters of the deformed steel tube were 1,070mm and 1,080mm respectively, and the diameter after expansion/correction was $1,100 \mathrm{~mm}$. As the original diameter of the specimen was $1,100 \mathrm{~mm}$, we could see that the restoration ratio was about $100 \%$. There also was no change in the thickness of steel tube as $14 \mathrm{~mm}$.

Table 10. Result of Tube Expansion Test

\begin{tabular}{|c|c|c|c|}
\hline Steel Type & Classification & Diameter $(\mathrm{mm})$ & Thickness $(\mathrm{mm})$ \\
\hline \multirow{2}{*}{ SM 490B } & Before Expansion & 1,070 & 14 \\
\cline { 2 - 4 } & After Expansion & 1,100 & 14 \\
\hline
\end{tabular}

Table 11. Result of C-TYPE JIG Test

\begin{tabular}{|c|c|c|c|}
\hline Steel Type & Classification & Diameter $(\mathrm{mm})$ & Thickness $(\mathrm{mm})$ \\
\hline \multirow{2}{*}{ SM 490B } & Before Expansion & 1,080 & 14 \\
\cline { 2 - 4 } & After Expansion & 1,100 & 14 \\
\hline
\end{tabular}

In conventional cases, when a partial deformation happens on the steel tube during the transportation or field construction, the tube was moved to the plant for the restoration because it might give serious damage to the structure durability, causing much temporal and economic loss. But, when the portable tube expander or C-TYPE JIG is used, the workability can be greatly improved because the partial deformation is directly corrected in the field.

\section{Basic Test Plan for Orbital Welder and Test Results}

\subsection{Basic Test Plan for Orbital Welder}


While the steel tube manufacturers usually have their own welding machines to improve the production efficiency of steel tubes, the joint welding of steel tubes in the field is mainly carried out by welding technicians. In other countries, automatic welding systems (McPherson, 2012) have been developed and widely used. But, in Korea, there have been no such cases. The welding by welding technicians usually has low work efficiency, high labor cost and low work quality. To solve this problem and improve the quality and efficiency of welding, an orbital welding machine was developed, as shown in Table 12.

Table 12. Specification of Orbital Welder

\begin{tabular}{|c|l|}
\hline Division & \multicolumn{1}{c|}{ Description } \\
\hline $\begin{array}{c}\text { Basic } \\
\text { Specification }\end{array}$ & $\begin{array}{l}\text { Specification of Main Body: } 1090 \times 610 \times 970 \mathrm{~mm} \\
\text { Output Power: } 96.8 \mathrm{v} \text { (voltage without load) } \\
\text { Use Range: } 0 \sim 20(4 \mathrm{roll}) \mathrm{m} / \mathrm{mm}\end{array}$ \\
\hline Features & $\begin{array}{l}\text { Easy to move and re-install, little restriction in location, and auto welding } \\
\text { possible. }\end{array}$ \\
\hline $\begin{array}{l}\text { Welding } \\
\text { Method }\end{array}$ & $\begin{array}{l}\text { The circular orbit is installed around the steel tube and the welding is carried } \\
\text { out along the orbit. It is good for complex tube welding. }\end{array}$ \\
\hline
\end{tabular}

\subsection{Test Method of Orbital Welder}

After joining two steel tubes with same diameter and thickness head to head, the joint welding was carried out, measuring the welding time. The result was compared with that when the welding was carried out conventionally by a welding technician. The welding method was set as AUTO. The specification of specimen is presented in Table 13.

The test order of Orbital Welder is shown in Figure 8 or as follows:

(1) Two circular steel tubes with same dimension are prepared for the joint welding. 
(2) Install the welder rail inside the prepared steel tubes and set the welding machine as AUTO.

(3) Operate the Orbital Welder while checking the time.

(4) On finishing the welding, stop the time measurement and check if there are any problems on the welded surface.

(5) Compare it with joint welding done by a welding technician.
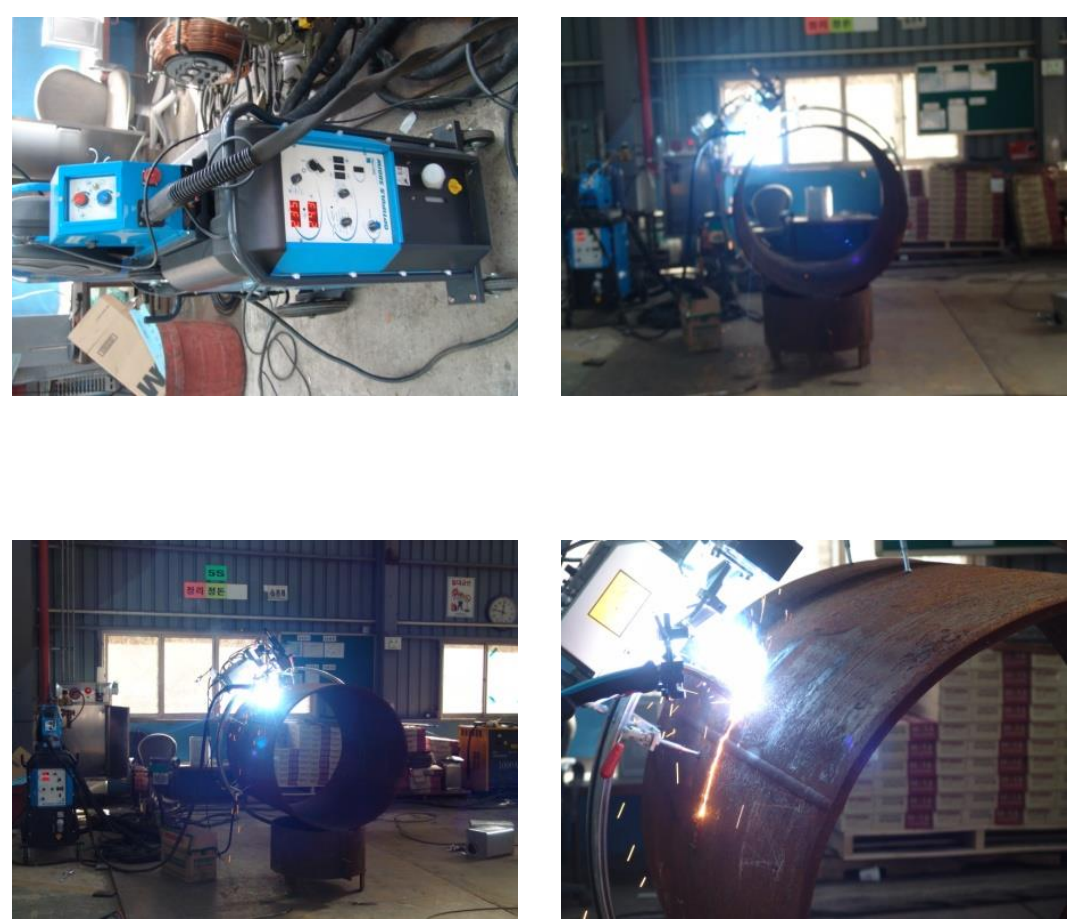

Figure 8. Orbital Welding Test

Table 13. Specification of Specimen

\begin{tabular}{|c|c|c|}
\hline & Orbital Welder & Welding Technician \\
\hline Steel Type & SM400B \\
\hline$\varnothing$ & $1000 \mathrm{~mm}$ \\
\hline $\mathrm{t}$ & $12 \mathrm{~mm}$ \\
\hline
\end{tabular}




\subsection{Test Result of Orbital Welder and Discussion}

The test result of Orbital Welder is shown in Table 14. When the welding amount of Orbital Welder was compared with that of welding technician, the work time for each tube was 3.3 times, the daily work amount was 4 times and the ratio of power consumption to wage was more efficient than 1.6 times.

Table 14. Test Result of Orbital Welder

$<$ Cost for welding materials is excluded $>$

\begin{tabular}{|c|c|c|c|}
\hline \multicolumn{2}{|c|}{ Orbital Welder } & \multicolumn{2}{c|}{ Welding Technician } \\
\hline $\begin{array}{c}\text { Work Time for each } \\
\text { tube }\end{array}$ & $45 \mathrm{~min}$ & $\begin{array}{c}\text { Work Time for each } \\
\text { tube }\end{array}$ & $150 \mathrm{~min}$ \\
\hline $\begin{array}{c}\text { Daily Work Amount } \\
\text { Power } \\
\text { Consumption }\end{array}$ & $12 \mathrm{ea}$ & Daily Work Amount & 3 ea \\
\hline
\end{tabular}

As the welding can be carried out automatically, it can reduce the labor cost and increase the human efficiency at the same time. Furthermore, it is easy to control the welding quality. As the high-strength steel tubes have thin thickness, it may give us great improvement in economy, workability and efficiency when continuous research and standardization are carried out.

\section{Conclusions}

This study proposes a consecutive manufacturing system to secure the productivity of high steel tubes. The consecutive manufacturing system comprises the press bending, the 
Orbital auto welding and the steel tube correction. Unlike ordinary steel materials, high strength steel material of low yield point such as STKN540B requires some special manufacturing process. By using such steel material, an actual steel tube is manufactured, and the quality of the steel tube and the efficiency of its manufacturing process are analyzed to draw out the issues for future improvement. If the consecutive process system proposed in this study is applied to the structure materials for mega structures such as building, bridge and ship in the future, it will greatly contribute to expanding the use of high strength steel tubes with high economy and safety..

\section{Acknowledgements}

This research was supported by the faculty research fund of Sejong University in 2019.

\section{References}

1. W. W. Yu (1999) 'Cold-formed steel structures, Structural Engineering Handbook,' (ed. Chen Wai-Fah and Boca Raton), CRC Press LLC.

2. G. J. Hancook (2003) 'Cold-formed steel structures,' Journal of Constructional Steel Research, Vol. 59(4), 473-487.

3. S. W. Im, K. Choi, and I. H. Chang (2004) 'Evaluation of Forming Performance of Cold Rolled Steel Pipes \& Tubes for Building Structure,' Journal of Korean Society of Steel Construction, Vol. 16(1), 33-42.

4. J. Yanagimoto, K. Karhausen, A. J. Brand, and R. Kopp (1998) 'Incremental Formulation for the Prediction of Flow Stress and Microstructural Change in Hot Forming,' Journal of Manufacturing Science and Engineering, Vol. 120(2), 316-322.

5. H. Gueler (2013) 'Investigation of Usibor 1500 Formability in a Hot Forming Operation,' Materials Science, Vol. 19(2), 144-146.

6. F. Lopes, A. Santiago, L. S. da Silva, N. Iqbal, M. Viljkovic, J. G. S. da Silva (2015) 'Sub-frames with reverse channel connections to CFT composite column-experimental evaluation,' Advanced Steel Construction, Vol. 11(1), 111-126.

7. S. Morino, M. Uchikoshi, and I. Yamaguchi (2001) 'Concrete-Filled Steel Tube Column System-Its Advantages,' Steel Structures, Vol. 1, 33-44. 
8. J. Y. Park and M. J. Lee (2013) 'Structural Characteristic of Beam-to-Column Connections in Rectangular CFT Structures Considering Concrete Filling,' Journal of Korean Society of Steel Construction, Vol. 25(2), 187-196.

9. J. R. Kim, S. S. Kim, C. H. Lee, E. T. Lee, and K. Y. Beak (2008) 'A Study on the Material Characteristics and the Welding Properties of 600MPA Grade Steel (SM 570 TMC), Journal of Korean Society of Steel Construction, Vol. 20(6), 773-781.

10. W. E. Luecke, J. D. McColskey, C. N. McCowan, S. W. Banovic, R. J. Fields, and T. Foecke, T. A. Siewert, and F. W. Gayle (2005) 'Federal Building and Fire Safety Investigation of the World Trade Center DisasterMechanical Properties of Structural Steels,' NIST NCSTAR 1-3D, NIST, USA.

11. H. L. Peng, F. Zhou, and L. W. Tong (2012) 'Experimental Investigation of Cold-Formed Steel Tubes Subjected to Web Crippling,' Applied Mechanics and Materials, Vol. 166-169, 322-328.

12. H. Watari and H. Ona (2001) 'Cold-roll forming of small-diameter pipes with pre-notches,' Journal of Materials Processing Technology, Vol. 119, 122-126.

13. M. Moles and E. Ginzel (2012) 'Phased Array for Small Diameter,' Thin-Walled Piping Inspections, $18^{\text {th }}$ World Conference on Nondestructive Testing, Durban, South Africa.

14. J. W. Cho, Y. C. Seo, S. H. Jung, S. H. Kim, and H. K. Jung (2007) 'Defect detection within a pipe using ultrasound excited thermography,' Nuclear Engineering and Technology, Vol. 39(5), 637-646.

15. H. S. Iyengar (1972) 'Preliminary Design and Optimization of Tall Buildings,' Proceedings, International Conference on Tall Buildings, Lehigh University., Vol. II.

16. M. M. Ali and K. S. Moon (2007) 'Structural Developments in Tall Buildings: Current Trends and Future Prospects,' Architectural Science Review, Vol. 50(3), 205-223.

17. T. Okui, K. Kuroda, and M. Akiyama (2006) 'Die design for reducing tube outside diameter by cold pressing and mechanism of thinning and bending phenomenon,' Ironmaking \& Steel making, Vol. 33(3), 223-228.

18. V. A. Ceclan, N. Balc, A. V. Niron, C. Borzan, and A. Popan (2011) 'Numerical simulation of the tube bending process and validation of the results,' Academic Journal of Manufacturing Engineering, Vol. 9(3), 32-37.

19. W. G. Cha and N. S. Kim (2013) 'Study on twisting and bowing of roll formed products made of high strength steel,' International Journal of Precision Engineering and Manufacturing, Vol. 14(9), 1527-1533.

20. S. Zhu and Y. Matsubara (1996) 'Proposal for a tube expander,' Cryogenics, Vol. 36(6), 403-408.

21. N. A. McPherson (2012) 'Welding automation in shipbuilding and influence of materials,' Ironmaking \& Steel making, Vol. 39(7), 483-486.

22. K. H. Ahn, J. S. Kim, and H. Huh (2008) 'The effects of local buckling on the crash energy absorption of thin-walled expansion tubes,' Numisheet 2008, 799-804, September 1-5, Interlaken, Switzland.

23. W. H. Song, D. H. Seo, and J. Y. Yoo (2009) 'Development Trend of Linepipe Steel and Its Weldability,' Journal of KWJS, Vol. 27(1), 34-48.

24. H. W. Lee, J. H. Bae, M. S. Kim, and C. Kim (2011) 'Optimum design of pipe bending based on highfrequency induction heating using dynamic reverse moment,' International Journal of Precision Engineering and Manufacturing, Vol. 12(6), 1051-1058.

25. R. A. Silva, G. Z. Batista, L. F. G. Souza, and I. S. Bott (2012) 'Effect of Varying High Frequency Induction Bending on the Longitudinal SAW Weld of API X80 Steel Pile,' Materials Science Forum, Vol. 706-709, 2059-2065.

26. D. Kim, D. Kang, and S. Rhee (2005) 'Determination of Optimal Welding Conditions with a Controlled 
Random Search Procedure,' Supplement to the Welding Journal, 125-130.

27. L. Xu, P. Zhou, Y. Chi, L. Huang, J. Ye, M. Yu (2017) Performance of the High-Strength Self-Stressing and Self-Compacting Concrete-Filled Steel Tube Columns Subjected to the Uniaxial Compression, International Journal of Civil Engineering, https://doi.org/10.1007/s40999-017-0257-9

28. J. H. Kim, Y. J. Cho, and Y. H. Jang (2013) 'Estimation of the weldability of single-sided resistance spot welding,' Journal of Manufacturing Systems, Vol. 32(3), 505-512.

29. S. K. Gupta (2002) 'Sheet Metal Bending: Forming Part Families for Generating Shared Press-Brake Setups,' Journal of Manufacturing Systems, Vol. 21(5), 329-350.

30. Q. W. Wang, J. F. Chen, X. Chen, Z. L. Gao, Y. B. Li (2019) 'Fatigue life prediction of steam generator tubes by tube specimens with circular holes', Vol. 9(3), 322.

31. H. Yang, H. Li, Z. Zhang, M. Zhan, J. Liu, and G. Li (2012) 'Advances and Trends on Tube Bending Forming Technologies,' Chinese Journal of Aeronautics, Vol. 25(1), 1-12.

32. D. K. Lee and S. M. Shin (2015) 'Specimen Test of Large-Heat-Input Fusion Welding Method for Use of SM570TMCP,' Advances in Materials Science and Engineering, Vol. 2015, Article ID 264798, 13 pages, http://dx.doi.org/10.1155/2015/264798

33. D. K. Lee and S. M. Shin (2014) 'Evaluating high performance steel tube-framed diagrid for high-rise buildings,' Steel and Composite Structures, Vol. 16(3), 289-303. 